\title{
Encouraging Family and Parent Education: Program Development and Evaluation in the Federal State of Baden-Württemberg, Germany
}

SAndra LandhäUsser ${ }^{1}$, Stefan FaAS ${ }^{2}$ And Rainer Treptow ${ }^{\star 3}$

$\approx$ Against the background of a European-wide strategy of governance aimed at improving support for parents and families, the following report details the conceptualization and evaluation of a federal state program ${ }^{4}$ in BadenWürttemberg (Germany) which was launched in 2008 to encourage family and parent education. Two program components, a voucher system for parents with a new-born child and an element that emphasizes educational offers for families with special needs in particular living situations, were started to increase requests for educational courses. The aim was to establish and deepen cooperation between different public and private professional services that are in contact with parents and their children. The results show that main goals of the program were reached.

Keywords: family and parent education, cooperation, voucher system, support for families with special needs in particular living situations, program evaluation

1 University of Tuebingen, Institute of Education, Department of Social Work, Tuebingen, Germany

2 University of Tuebingen, Institute of Education, Department of Social Work, Tuebingen, Germany

$3{ }^{*}$ Corresponding Author. University of Tuebingen, Institute of Education, Department of Social Work, Tuebingen, Germany; rainer.treptow@uni-tuebingen.de

4 The label STÄRKE represents Stärkung der Erziehungskompetenz (strengthening of educational competence). 


\section{Spodbujanje izobraževanja staršev in družin: razvoj in evalvacija programa v zvezni državi Baden - Württemberg v Nemčiji}

Sandra LandhäUsser, Stefan FaAs and Rainer Treptow*

$\approx$ Glede na to, da je široko po Evropi prisotna skrb za izboljšanje podpore staršem in družinam, v prispevku predstavljamo zasnovo in evalvacijo programa5, ki se je začel izvajati leta 2008 v zvezni državi Baden Württemberg (Nemčija), in sicer $z$ namenom spodbujanja povezovanja izobraževanja staršev in družin. Začeli smo z dvema programskima ukrepoma za povečanje povpraševanja po izobraževalnih tečajih. Prvi ukrep je bil uvedba sistema vavčerjev za starše z novorojenčki, ki je omogočil vključitev v različne oblike izobraževanja. Drugi ukrep je bil usmerjen $\mathrm{v}$ izobraževalno ponudbo za družne $\mathrm{z}$ otroki s posebnimi potrebami in družine s specifičnimi bivanjskimi razmerami. Namen programa je bil tudi poglobiti sodelovanje med različnimi javnimi in zasebnimi strokovnimi službami/ponudniki raznovrstne pomoči ter podpore za starše in družine. Evalvacija programa kaže na to, da so bili osrednji cilji izvedenega programa doseženi.

Ključne besede: družinsko in starševsko izobraževanje, sodelovanje, sistem vavčerjev, podpora družinam s posebnimi potrebami v specifičnih bivanjskih razmerah, evalvacija programa 


\section{Introduction}

In many European countries, and throughout the world, family policies have experienced an expansion in recent times, although various countries still display enormous diversity and dissimilar preferences (Blum \& Rille-Pfeiffer, 2010; Daly, 2013). Against this background, the topic of improving parent and family education has gained importance at all levels of politics (Euteneuer et al., 2011; Stauber, 2010; Uhlendorff, Rupp, \& Euteneuer, 2011). In Germany, in the course of addressing public responsibility for the support of parents and families, new and different concepts of learning opportunities for families have been developed. These concepts include formal courses and training as well as informal get-togethers, each containing varying topics and located at a variety of institutions. As several pilot projects have shown, the strengthening of parents' competence in educating and caring for their children is not only affected by the educational resources the parents may have gained independently but is also enhanced by additional learning possibilities that are affordable, accessible and attractive. Furthermore, families need increased support from a range of available social services (Evers, Heinze, \& Olk, 2011). Therefore, efficient and successful cooperation between social services and educational institutions has to be developed. This has to be done in the local community where children grow up and where parents are coping with the circumstances of life in order to fulfil their duties. Additionally, it is important to investigate how parents can be not only informed of but also convinced to participate in such offers while not fearing possible negative effects of stigmatization.

There are various strategies in educational and social politics to reach these goals. In Germany, two main methods can be identified. First, there are quite a number of federal states that focus on bringing an integrated framework of family support services, including family and parent education, to institutions that offer day-care facilities for children. ${ }^{6}$ These services are closely connected to international developments, where the positive effects of the involvement of parents in the institutional education of their children have been enhanced (Melhuish, Belsky, \& Barnes, 2010; Pascal et al., 2010). Other European countries, such as the Netherlands, also follow these developments (Busch et al., 2013). Second, there are federal activities to bring family education courses to young parents, either for free or with financial support. Examples include Elternstart (Parent Start) in North Rhine Westfalia and Viva Familia in Rhineland-Palatinate.

6 For example, see Ministry for Generations, Family, Women and Integration of the federal state North Rhine-Westphalia, 2009; Sturzenhecker, 2009. 


\section{Improving Family and Parent Education in Baden - Württemberg: The STÄRKE Program}

In 2008 in Baden - Württemberg, a federal state of Germany, which is located in the southwest of the country, ${ }^{7}$ the STÄRKE program, a voucher system together with aid for parents with special needs in particular living situations, was introduced. ${ }^{8}$ The main goals of the program are:

- to facilitate access to educational opportunities and services for parents of infants and for families with special needs in particular living situations,

- $\quad$ to emphasize the significance of parent and family education and promote the enhancement of an area-wide network of educational opportunities for parents and families,

- $\quad$ to provide access to continuing advice for families with special needs in particular living situations, alongside and after participation in a specific course, and

- $\quad$ to expand cooperation between institutions providing education to parents and families and other social services and professionals that engage in family healthcare, educate children or protect them from abuse or violence.

These goals shall be reached using the following components of the program:

- $\quad$ awarding of vouchers for all parents of new-born infants, and

- the advancement of specific supplies for families with special needs in particular living situations.

Since ${ }^{\text {st }}$ September 2008, all parents of new-born infants have received a voucher amounting to 40 euros when they give birth or start a permanent fosterage or adoption. The vouchers are sent by mail or are personally delivered by municipal staff. Redemption must be made within one year of the child's birth. Parents and guardians can either choose a course, which costs 40 euros, or a more expensive course to which the voucher is credited. Examples of course topics include child-development, developmental psychology and nutrition, communication within the family, and being a father/mother. Vouchers in this program are characterized by several attributes. They are, in a sense, equivalent

7 Baden-Württemberg has approximately 11 million inhabitants and about 1.6 million families. The annual birth rate is about 89,000 .

8 See Ministry for Labour and Social Affairs, Family, Women and Elderly People BadenWürttemberg $(2008,2010)$. 
to money, but are nevertheless strongly embedded within an educational opportunity with a defined time frame. Vouchers generally produce a high degree of awareness of the program in the population and are attractive because of positive experiences in the private and public sector of giving, receiving and redeeming them (Daniels \& Trebilcock, 2005; Dohmen, 2005). Nevertheless, there is no obligation to accept or redeem them, which means that the sovereignty of the parents to decide is completely respected. Moreover, parents need not fear being stigmatized as being poor because the vouchers are given to all parents after birth of a child independent of other requirements. The voucher has and should continue to facilitating access to and participation in parental education and to reducing financial and symbolic barriers.

The second component of the program focuses on particular living conditions, i.e. on challenges that strain families excessively and that can lead to specific risks in child development. Regardless of the child's age and also prior to birth, families with special needs in particular living situations can attend specific educational events for free. Up to 500 euros are available for every family. These offers are secondary preventive measures through which parents are given strategies to cope with stressful situations in order to avoid the possible negative effects of being overloaded. It is important to work with a conception that is structured for the specific target group, that enables approaching the families actively and that includes methods and exercises that are close to their everyday life. The courses aim to strengthen the knowledge base of families concerning interaction with the child and to offer coping strategies regarding the circumstances of life in general (Goldstein \& Brooks, 2006). In case these parents need further advice, they can apply for additional home visits.

The combination of the voucher with specific support for families in particular living situations (e.g. families with a migration background, single parents, and families with chronically ill or handicapped members ${ }^{9}$ ) modifies the idea of general support and adds focus on specific target groups. Thereby, unrealistic expectations concerning the coverage of primary preventive arrangements can be reduced (Barnett, 1995; Yoshikawa, 1995). This second component, together with the vouchers, shows sensitivity to problems parents may face and discourages one-sided perspectives of such problems. To evaluate these claims, a set of questions has been produced. The questions are: How many parents used the voucher? How many offers were for families with special needs in particular living situations? What social background did the families

9 Ten particular living situations are named as a specification by the program. Additionally there is an $11^{\text {th }}$ category called "others", under which the educational providers are free to provide courses for families with special needs in others, not yet named, living situations. 
come from? What learning opportunities were offered, and which were chosen? Were new parents who were not familiar with the opportunities reached? The following report provides the answers to these and other questions.

\section{The Evaluation: Research Questions and Methods}

The evaluation of the STÄRKE program, which was done by the Institute of Education at the University of Tuebingen between 2009 and 2012, mainly focused on the following issues (Treptow, Landhäußer, \& Faas, 2013):

- claiming of the voucher and its importance in the choice of specific offers,

- the support of families with special needs in particular living situations,

- the organization and design of correspondent arrangements, and

- the structural and organizational enhancement of parent and family learning within the program, especially in regard to changes in the general structure of supply of services and deepening of cooperation between youth welfare offices, educational institutions and other professional services.

For these purposes, we used annual accounting sheets from all youth welfare offices (2009: $\mathrm{N}=48 ; 2010: \mathrm{N}=48 ; 2011: \mathrm{N}=47$ ). Their analysis focused on the number of redeemed vouchers, the topics of the visited courses, the offers for families with special needs in particular living situations, the target groups reached and the involvement of educational institutions. To show the developments of these facets within the program, the accounting sheets were analysed annually. Other aspects were investigated via the online surveying of staff from youth welfare offices (2009: $\mathrm{N}=47 ; 2010$ : $\mathrm{N}=47 ; 2011: \mathrm{N}=46$ ) and from educational institutions (2010: $\mathrm{N}=245 ; 2011: \mathrm{N}=235$ ) to explore the perspectives of the involved professionals. The opinions and characteristics of parents were examined through a written questionnaire for parents ${ }^{10}(\mathrm{~N}=471)$ and course participants who either redeemed a voucher $(\mathrm{N}=131)$ or took part in an arrangement for families with special needs in particular living situations $(\mathrm{N}=458)$. Additionally, three interviews (2009, 2010 and 2012) with a staff member of the federal youth welfare office who coordinates the program were analysed. As a final step, the different perspectives of the individuals involved were related and discussed with respect to selected aspects.

10 In selected districts, for four months we sent a questionnaire to all parents with a newborn child. 


\section{Main Results}

The following main results refer to questions about the vouchers and their importance for parents' participation in family-based learning possibilities 1), about the use of offers for special target groups by families with special needs in particular living situations 2) as well as about the general structural and organizational enhancement of parent and family learning 3) within the STÄRKE program.

\section{Educational Vouchers}

In judging the educational vouchers, the following questions were used:

- How many vouchers were redeemed and how did this number change in the process of the program? Which educational opportunities did parents choose?

- What correlations can be found between the rate of redemption and specific structural as well as organizational circumstances in the different administrative districts?

- What relevance did the vouchers have for the attendance of parents in family-based learning opportunities?

- To what extent did they change the structure of the participants in such offers?

\section{Redemption of the vouchers}

Statistical analyses of the annual accounting sheets of the youth welfare offices showed that the number of redeemed vouchers as well as the redemption rate expanded extensively during the development of the program. In 2009, at the beginning of the program, 14,624 vouchers were used (redemption rate: $16.3 \%$; $\mathrm{SD}=4.83$ ); in 2010, 23,520 were redeemed (25.9\%; $\mathrm{SD}=6.05)$; and in 2011, 26,492 vouchers were used $(29.8 \% ; \mathrm{SD}=6.74)$. This means that, in 2011 , nearly one third of all families with new-born infants in Baden-Württemberg made use of a voucher. With regards to content, most parents visited a PEKIP ${ }^{11}$ (Prague ParentChild Program) course, which had been established before STÄRKE. Courses that were developed specifically for the program and that teach basic information on children's development within the first year were also in demand. In the course of the program, requests for alternative types of courses increased. For example, requests for courses such as "baby massage" rose. Based on the different 
administrative districts, there were large differences between redemption rates. For the year 2009, they differed between $4.9 \%$ and $29.4 \%$, for 2010 , between $11.2 \%$ and $39.3 \%$ and for 2011 , between $11.8 \%$ and $45.5 \%$. The percentage increase from 2009 to 2011 was between $3.9 \%$ and $24.6 \%$. These great variations relating to redemption rates and changes in the development of STÄRKE suggest that the structural and organizational circumstances of the implementation of the program were different in the various districts. Furthermore, there seem to have been correlations between specific conditions and voucher redemption.

\section{Correlations between voucher redemption and structural and organizational conditions in the administrative districts}

Analyses related to the different administrative districts showed significant correlations ${ }^{12}$ between the structural and organizational conditions, which were investigated by surveying the youth welfare office staff, and the redemption of vouchers. The following aspects seemed to be of special importance:

Area-wide opportunities. Higher redemption rates correlated significantly with increases in area-wide opportunities for family and parent courses. To act on area-wide possibilities as needed is a central goal of the program, which is directly linked to its successful implementation. Against this background, another result was remarkable. An area-wide expansion of the opportunities for parent education courses correlated with an increase in cooperation between youth welfare offices and medical centres, nursery schools and schools. This seems to be plausible as, because of their local proximity, such institutions have the potential to develop opportunities in the neighbourhood and based on local needs (Axford et al., 2012).

Cooperation between youth welfare offices, educational institutions and other partners. There was a significant correlation between an increase in voucher redemption and an increase in extensive cooperation between youth welfare offices and educational institutions that provide education courses for parents and families. Furthermore, a correlation was seen between an increase in redemption rates and an increase in cooperation between youth welfare offices and other partners. Cooperation with medical doctors and with actors from nursery schools with respect to common advertisements for the program was emphasized. Such cooperation is another central goal of the program and is linked to its successful implementation.

12 We consciously and restrictively refer to correlations and not to causally determined impacts. The latter cannot be assured on the basis of the available data, which may be also liable to different selection processes (Legewie, 2012). Concerning their plausibility, the reported correlations are therefore to be interpreted in the context of other research outcomes and theoretical considerations. 
Personal delivery of the voucher. In several communities, the STÄRKE vouchers were not sent by mail but were handed out in personal face-to-face contact. The expectation that direct contact with the parents positively influences their redemption is one of the reasons to do so. This expectation may apply in single cases, but on the basis of the collected data, no correlation between a personal hand over and the redemption rate could be found. It has to be mentioned that the personal hand over was only done in a few communities so that these cases built only a small part of the total sample. This means that the result has to be interpreted carefully because, on the basis of the collected data, influences of other variables cannot be excluded. A final judgment on this aspect would have to be made after analysing a larger sample.

\section{The voucher's importance for participation in parent and family educational events and changes in the participants' structure.}

The analysis of answers by parents who redeemed their voucher shows that it drew their attention to possibilities of parent and family education. Furthermore, it gave an incentive to participate in the courses: $23 \%$ of the surveyed parents said that without the voucher they would have been less attentive to the offers for parents including to the offer for the course they attended; $33 \%$ indicated that without the financial support of the voucher they would not have joined. With respect to the point in time for participation in the course, over $15 \%$ of the parents said that without the voucher they probably would have not participated in a course within the first year of their child's birth. Additionally, the results show an impact of the vouchers on course content. More than $34 \%$ of parents specified that the voucher influenced their choice of the course topic.

The results allow the conclusion that the majority of parents who redeemed the voucher would have participated in the courses without the financial support. Therefore, it should not be overlooked that with the help of the voucher a number of parents were also encouraged to participate who otherwise would not have done so. Related to the present analysis, this is true for one third of the respondents. This reading of the outcomes is supported by the results of the educational institution's survey. More than $30 \%$ of the respondent staff members indicate that in the context of the STÄRKE program the participants' demographic structure in the educational meetings changed noticeably. Specifically, they especially refer to the increasing publicity of the program and the financial incentive of the voucher. Several organizers report an enlarged participation of young mothers, parents with a migration background, single parents as well as parents with a low socioeconomic status. 


\section{Offers for Families with special Needs in Particular Living Situations}

With regard to a detailed assessment of the courses for families with special needs in particular living situations the following questions were used:

- How many parents participated in the meetings for families with special needs in particular living situations?

- How did this change in the progress of the program?

- Which group-specific events were chosen by parents and with what frequency in the entire federal state?

- To what extent is individual counselling in a home visit related to course attendance?

- What relations exist between a large dissemination of realized courses and specific structural and organizational conditions in the urban and rural districts?

- Who attends the courses for families with special needs in particular living situations?

- How do the participants evaluate the chosen courses?

\section{The use of offers for families with special needs in particular living} situations

Statistical analyses of the annual accounting sheets administered by youth welfare offices showed that the number of families with special needs in particular living situations that participated in a correspondent event in the context of STÄRKE increased continuously. In relation to the first year, 2009 $(3,529)$, the number of participants doubled in the second year $(8,672)$ and more than tripled in $2011(12,047)$. With respect to this result, a clear increase in the number of families was attained. Furthermore, the number of claimed home visits showed a growth of more than doubled between 2009 (292) and 2011 (673). See Figure 1. 


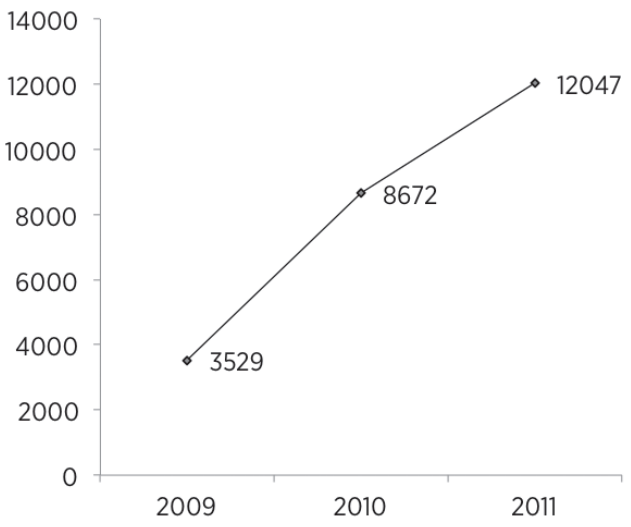

Figure 1. Participation of families in particular living situations in groupspecific educational events (total numbers). ${ }^{13}$

The rate of home visits, related to all attended courses, was between $5 \%$ and $8 \%$. The educational institutions survey indicated that half of the institutions that offered events for families with special needs in particular living situations provided courses with additional home visits.

Comparing the particular living situations of parents who attended a course between 2010 and 2011, there was an increase in participation at events for parents in "other" living situations. In other words, there was an increase in courses that were provided for particular target groups that were not mentioned in the program. This can be interpreted as indicating that the educational institutions use the runtime of the program to develop and establish courses for new living situations not previously taken into account. In general, most families with a migration background were addressed and reached (approx. 4,000). This also applied to single parents (approx. 3,500). In both groups, there was an essential growth in numbers between 2010 and 2011. The third largest group was families with members affected by illness or disability (approx. 1,600). All other groups combined amounted to less than 700 participants (related to the year 2011).

With respect to distribution in the particular districts, it can be seen that, with the exception of one district, there was an increase in the numbers of course offers between 2009 and 2011. For a few districts, which started with low numbers in 2009, the increase was more than tenfold. This increase in numbers coincided with significant area-wide growth of course offers, as stated by staff

13 Source: KVJS (Kommunalverband Jugend und Soziales/federal youth welfare office), own calculation 
of the youth welfare offices. Relating the sum of families reached to the average number of births within a year (considering the size of a district), ${ }^{14}$ it can be seen that in 2011 an average of $14 \%$ of families were reached. In many districts, between $4 \%$ and $24 \%$ were reached up to a maximum of more than $40 \%$. Comparing the districts, as in the federal state-wide numbers, most courses were for families with migration backgrounds, single parents and families with members affected by illness or disability.

\section{Correlations between the use of offers for families in particular living situations and structural and organizational conditions in the urban and rural districts}

On the basis of correlation analyses, the following relations between the rate of families reached and different structure and framework requirements in the districts were found. ${ }^{15}$

Area-wide expansion of supply, growth in numbers and integration in early support. Just as with the redemption of the vouchers, a significant correlation between the number of reached families and area-wide expansion of course offers can be shown. This aligns with the fact that area-wide enlargement of educational offers is a central goal of STÄRKE and of great importance for successful implementation of the program. In addition, there are smaller but still significant correlations between the number of offers and their integration in early support. The correlation is even increased if there is an overall concept of how to integrate early support in STÄRKE.

Cooperation between youth welfare offices, educational institutions and other partners. There was a rather significant correlation between the number of families reached in particular living situations and more intensive collaboration between youth welfare offices and different educational institutions in the context of STÄRKE. Mainly, the common planning of the course content was relevant, meaning that use was higher when there was cooperation between youth welfare offices and educational institutions. Furthermore, the participation of youth welfare offices in a program design relating to requirements for course construction seemed to be essential, whereas proposals and examinations with respect to the supply of courses were of less importance. Considering the different institutions that took part in STÄRKE during the survey, the

14 Although the courses of component two relate not only to parents with children aged one year and below, we relate attendance at courses as a whole to birth rates, not to calculate a concrete number of reached families but to imply the size of a district by estimating a relative number on the basis of the birth numbers. Based on this, correlations between this number and specific framework requirements can be investigated.

15 As in the analysis of the data on the vouchers above, we speak here about correlations and not about causal impacts. 
use of courses was higher if schools were involved in the implementation of the program. In addition, there were positive correlations if the health sector (hospitals, medical practitioners and midwives) as well as nursery schools were included in the advertisement. Similarly, correlations existed between reaching families with special needs in particular living situations and the use of schools and hospitals as places to hold courses. This also held true for the involvement of schools and nursery schools in the delivery of courses. Finally, the cooperation between youth welfare services and different institutions, as in the areawide expansion of offers, was seen to be a central goal and a main aspect of fruitful implementation.

\section{Groups of participants and their evaluations of the educational offers.}

On the basis of the participants' survey, it can be documented that parents with special needs in particular living situations, which attended a course, were on average 38 years old. As for their educational achievement, almost one quarter of the respondents had a Hauptschule (minimum 9 years of formal education) certificate, $35 \%$ a Realschule (minimum 10 years of formal education) certificate, and $35 \%$ a diploma for 13 years or more (general qualification for university entrance, university diploma etc.). ${ }^{16}$ Almost 90\% speak German at home and 10\% another language; $20 \%$ joined a course together with their partners. The most common type of family was a family with two children, followed by families with either one or three infants and finally by families with four or more children. The average age of the infants was nine years. Almost $4 \%$ of them were in their first year and one third of them of preschool-age ( $0-5$ years). Around $80 \%$ of the respondents were female. Thus, with respect to the participants, several characteristics were revealed relating, for example, to their sex/gender, number of children and language they speak at home. At the same time, they showed a broad range in terms of the parents' and children's ages as well as the educational levels of the parents. With regard to the evaluation of the courses joined, nearly all participants agreed that the event was helpful in retrospect. They were also in agreement about attending such a course again should they have a chance to do so. It is apparent that the parents felt positively about the atmosphere of the events and that they felt that their individual living situation was considered in the particular course. The satisfaction with the support of the home visits was also predominantly and positive.

16 almost 5\% had another school certificate or none 


\section{General Structural and Organizational Developments}

Relating to structural and organizational advancements within the field of parent and family education in the years 2009 to 2011, the following questions were considered:

- Which developments appear with respect to the structure of supply within the field of parent and family education in general?

- Which developments arise relating to the support for families in particular living situations?

- How does the cooperation between youth welfare offices, educational institutions and other professional services change and deepen?

\section{Developments in the structure of supply}

Statistical analyses of the annual accounting sheets and the surveys of the staff of the youth welfare offices show that the general course supply as well as attendance rates rose significantly within the time of the survey. This assessment was shared by all youth welfare offices. At the same time, they registered a significant growth with respect to a regional area-wide expansion of educational offers. There was also a significant improvement in area coverage reached even though some youth welfare offices admitted that full area coverage was not achieved.

There were similar developments relating to specific courses for families with special needs in particular living conditions. Here also, the course supply as well as requests for courses rose significantly. Furthermore, there was a significant area-wide increase in approved special programs. Nevertheless, there were districts in which this area-wide growth did not apply. In total, nearly all youth welfare office districts showed an area-wide increase in their supply, whether relating to voucher courses, to specific events for families in particular living situations or to both. The courses for families with special needs in particular living situations were predominantly integrated into a concept of early support.

Cooperation of youth welfare offices, educational institutions and other professional services

The results of the survey on youth welfare office staff also showed changes with respect to the cooperation of the involved actors. With regards to to the collaboration between youth welfare offices and educational institutions as well as between the educational institutions themselves, there was a significant intensification of relationships. Considering the stakeholders that were involved 
in the implementation of STÄRKE during the study, the inclusion of midwives increased the most, followed by nursery schools. Medical practitioners, hospitals and schools each showed the third largest increase, followed by day care institutions.

When interpreting this cooperation in the context of the whole program, the most significant developments were shown with respect to hospitals and midwives. Here, cooperation was increased or even built for the first time. As for the medical practitioners, some contacts were built in the context of STÄRKE while others existed before. Finally, with respect to the cooperation with nursery schools, primary and secondary schools as well as day care facilities, the outcome was high intensification within STÄRKE. Against this background, it can be demonstrated that in the domain of cooperation between youth welfare offices, educational institutions and other professional services, major developments were initiated in the context of STÄRKE.

\section{Conclusion}

Within expert discourse in Germany and in other European countries, parent and family education as a field of action is affected by structural challenges. These challenges arise as the field is located structurally in child and youth welfare as well as in adult education. In this context, unreconciled and partly reconciled support structures exist, which complicates the implementation of programs. The following points have been criticized: lack of a course's appropriate fit, the complexity of providers and supply structures, a lack of transparency and perceptibility, an absence of cooperation structures, and limitations in reaching parents, especially those in difficult living situations. Against this background, a need for better linking-up, matching and recognition of courses, the creation of interfaces and central supervision has been advanced (Daly, 2013; Rupp \& Smolka, 2007).

The STÄRKE program incorporates fundamental elements from expert discourses on the creation of modern family and parent education. It focuses on an improvement in the public perception of family and parent education and puts an emphasis on its significance. Furthermore, it seeks to develop a countrywide network of educational offerings for families and parents according to their needs. It stresses specific consideration for families in special and difficult living situations, the cooperation of youth welfare offices and educational institutions in parent and family education and the inclusion of other professional services and members of independent professions. In linking vouchers and offers to families with special needs in particular living situations, 
the program attempts a balance between providing general educational offerings for all parents and sensitive perceptions of various needs for support. This avoids negative labelling without negating families' problems. Such a conceptualization should be judged as ambitious.

The results show that in the course of the study the main goals of the program were reached. By the end of the survey, the number of course offerings as well as their area-wide presence was increased and it can be supposed that gaps in demand diminished. Furthermore, cooperation between youth welfare offices, educational institutions and other partners, including schools, day care facilities, doctors and midwives, increased significantly. The existing data show that the program has contributed to a new level of cooperation within the health sector. Additionally, the collaboration with other educational institutions has been deepened. These changes in the context of STÄRKE are simultaneously preconditions for better reaching parents, especially parents in difficult living situations. Towards these developments, both program components, the vouchers as well as the support for families with special needs in particular living situations, may have contributed.

The vouchers showed a close connection between an area-wide increase in educational offers and an increase in cooperation. In addition, they contributed to a better public recognition of parent and family education in BadenWürttemberg. Furthermore, there is evidence that the voucher was a medium to reach parents with special needs in particular living situations and was effective for specific target group offers. Moreover, they influenced the choice of course topics. Similar results can be found for the offers for families in particular living situations. They also have to be seen in the context of an increased area-wide dissemination of educational offers and an enlargement of cooperation between youth welfare offices, educational institutions and other partners in the public and private sector. The significant escalation of these offers over time underscores better inclusion of parents with particular needs for support.

\section{References}

Axford, N., Lehtonen, M., Kaoukji, D., Tobin, K., \& Berry, V. (2012). Engaging parents in parenting programs: Lessons from research and practice. Children and Youth Services Review, 34(10), 2061-2071.

Barnett, W. S. (1995). Long-term effects of early childhood programs on cognitive and school outcomes. The Future of Children, 5(3), 25-50.

Blum, S., \& Rille-Pfeiffer, C. (2010). Major trends of state family policies in Europe: Working report April 2010. Retrieved 27.1.2014 from http://www.familyplatform.eu/ 
Busch, V., Van Stel, H. F., De Leeuw, J. R. J, Melhuish, E., \& Schrijvers, A. J. P. (2013).

Multidisciplinary integrated parent and child centres in Amsterdam: A qualitative study.

International Journal of Integrated Care, 13(2). Retrieved 27.1.2014 from http://www.ijic.org

Daly, M. (2013). Politiken zur Unterstützung von Eltern in Europa. Entwicklung und Trends.

[Policies to support parents in Europe. Developments and trends]. In L. Correll \& J. Lepperhoff

(Eds.), Frühe Bildung in der Familie. Perspektiven der Familienbildung [Early Education in the Family.

Perspectives if family education] (pp. 146-159). Weinheim, Germany: Beltz Juventa.

Daniels, R. J., \& Trebilcock, M. J. (2005). Rethinking the welfare state: The prospects for government by voucher. New York, NY: Routledge.

Dohmen, D. (2005). Theorie und Empirie von Bildungsgutscheinen: Was können wir von den

Erfahrungen anderer Länder für die deutsche Diskussion lernen? [Theory and empirics of education vouchers: What can we learn from the experiences of other countries for the discussion in Germany?]. Köln, Germany: Forschungsinstitut für Bildungs- und Sozialökonomie.

Euteneuer, M., Farrer, L., Lay, W., Liedekerke, A. C., \& Uhlendorff, U. (2011). Families: A summary of the situation in Europe today. Retrieved 27.1.2014 from http://www.familyplatform.eu/

Evers, A., Heinze, R. G., \& Olk, T. (Eds.) (2011). Handbuch Soziale Dienste [Handbook of social services]. Wiesbaden, Germany: Verlag für Sozialwissenschaften.

Goldstein, S., \& Brooks, R. B. (Eds.) (2006). Handbook of resilience in children. New York, NY: Springer.

Legewie, J. (2012). Die Schätzung von kausalen Effekten: Überlegungen zu Methoden der Kausalanalyse anhand von Kontexteffekten in der Schule. [The estimation of causal effects: An introduction to methods of causal inference based on peer effects in education]. Kölner Zeitschrift für Soziologie und Sozialpsychologie, 64, 123-153.

Melhuish, E., Belsky, J., \& Barnes, J. (2010). Sure Start and its evaluation in England. In Encyclopedia on Early Childhood Development. Retrieved 27.1.2014 from http://www.child-encyclopedia.com/ documents/Melhuish-Belsky-BarnesANGxp.pdf

Ministry for Labour and Social Affairs, Family, Women and elderly People Baden-Württemberg. (2008). Rahmenvereinbarung zur Umsetzung des Programms STÄRKE (RV STÄRKE) nach dem Ministerratsbeschluss [General Agreement to the Implementation of the Program STÄRKE]. Retrieved 12.12.2013 from http://www.sm.baden-wuerttemberg.de/de/STAeRKE/188372.html Ministry for Labour and Social Affairs, Family, Women and elderly People Baden-Württemberg. (2010). Verwaltungsvorschrift des Sozialministeriums zur Förderung von Elternkompetenzen im Rahmen des Programms STÄRKE (VwV STÄRKE) [Administrative Instructions of the Ministry of Social Affairs to the Enhancement of Parents' Competence within the Program STÄRKE]. Retrieved 12.12.2013 from http://www.sm.baden-wuerttemberg.de/de/STAeRKE/188372.html Ministry of Generations, Family, Women and Integration of the federal state North RhineWestphalia. (2009). Familienzentren in Nordrhein-Westfalen: Neue Zukunftsperspektiven für Kinder und Eltern. Ergebnisse der wissenschaftlichen Begleitung im Überblick [Family centres in North Rhine-Westphalia: New future perspectives for children and parents. Results of the scientific 
supervision at a glance]. Retrieved from http://www.familienzentrum.nrw.de/fileadmin/documents/ pdf/publikationen/wissbegleitung.pdf

Pascal, C., Bertram, T., Gasper, M., Mould, C., Ramsden, F., \& Saunders, M. (2010). Research to inform the evaluation of the Early Excellence Centres pilot programme. Retrieved 27.1.2014 from www. education.gov.uk/publications/eOrderingDownload/RR259.pdf Rupp, M., \& Smolka, A. (2007). Von der Mütterschule zur modernen Dienstleistung: Die Entwicklung der Konzeption von Familienbildung und ihre aktuelle Bedeutung. [From mother's school to modern services: The development of the concept of family education and its current meaning]. Zeitschrift für Erziehungswissenschaft, 10(3), 317-333.

Stauber, B. (2010). Transitions into parenthood. Retrieved from http://www.familyplatform.eu/ Sturzenhecker, B. (2009). Eltern-Kind-Zentren in Hamburg: Bericht der Evaluation 2008/og [Parentchild centres in Hamburg: Report on the evaluation 2008/09]. Herausgegeben von Behörde für Soziales, Familie, Gesundheit und Verbraucherschutz. Hamburg, Germany: Freie und Hansestadt Hamburg.

Treptow, R., Landhäußer, S., \& Faas, S. (2013). Evaluation des Landesprogramms STÄRKE Forschungsbericht. Retrieved 31.1.2014 from http://www.sm.baden-wuerttemberg.de/fm7/1442/ ST\%C4RKE\%2oLangbericht\%2oCD_end.pdf Uhlendorff, U., Rupp, M., \& Euteneuer, M. (Eds.) (2011). Wellbeing of families in future Europe: Challenges for research and policy. Retrieved 24.1.2014 from http://www.familyplatform.eu/ Yoshikawa, H. (1995). Long-term effects of early childhood programs on social outcomes and delinquency. The Future of Children, 5(3), 51-75. 


\section{Biographical note}

SANDRA LANDHÄUSSER, dr. phil., is an academic staff member at the department of Social Pedagogy at the Eberhard Karls University of Tuebingen since 2008. Before that time she was a research associate at the "Center for Education and Capability Research" at the University of Bielefeld. Her research is focused on family and parent education as well as community oriented Social Work. Relations between neighborhood and social space, questions of social inequality and empirical answers on professional interactions in the community belong to her main interests in research and theory.

STEFAn FAAs, dr. phil., is an academic staff member at the department of Social Pedagogy at the Eberhard Karls University of Tuebingen since 2009. Before that he was a teacher at a vocational training school. His research is focused on early childhood education, knowledge of kindergarten teachers as well as family and parent education. Monitoring the quality of institutions for children, especially the kindergarten, and professional development of educational staff belong to his main interests in research and theory.

Treptow RAINER, dr. rer.soc., full professor, is holding a chair on educational science with special focus on Social Pedagogy at the Eberhard Karls University of Tuebingen since 2003. His main topics of research are theory and history of Social Work, internationalization of social support and forms of Arts Education. Before that time he was working as a professor for Social Pedagogy at the Friedrich Schiller University of Jena. 